\title{
Az ESC 2019-es, supraventricularis tachycardiával rendelkező betegek ellátására vonatkozó irányelvei. Összefoglaló
}

\author{
Szegedi Nándor*, Salló Zoltán*, Zima Endre, Merkely Béla, Gellér László
}

\author{
Semmelweis Egyetem, Városmajori Szív- és Érgyógyászati Klinika, Budapest \\ Levelezési cím: Dr. Salló Zoltán, e-mail: sallo.zoltan0121@gmail.com
}

\section{Bevezetés}

A supraventricularis tachycardiák (SVT) gyakoriak, és sokszor igényelnek gyógyszeres kezelést, vagy elektrofiziológiai beavatkozást, mivel a páciensek legtöbbször panaszosak. 2003 után hosszú ideig nem került kiadásra ezen betegek kezelését segítő irányelv. Jelen közlemény az Európai Kardiológus Társaság (ESC) 2019-ben megújított, SVT-k kezelésére vonatkozó irányelveit foglalja össze. Relevánsabb változtatások közül kiemeljük a tünetmentes preexcitációval bíró betegek rizikóstratifikációjának invazív irányba történő terelését, illetve a legtöbb SVT esetén az ablációs kezelés előtérbe kerülését. Külön említésre kerülnek speciális betegcsoportok, úgymint terhes páciensek, veleszületett szívfejlődési rendellenességgel élő betegek, sportolók, hivatásos soförök.

\section{Definíciók és osztályozás}

A supraventricularis tachycardia (SVT) magába foglal minden olyan tachycardiát (frekvencia >100/perc nyugalomban), amelynek mechanizmusában a His-köteg és a felette elhelyezkedő szövetek vesznek részt (1. táblázat).

\section{Supraventricularis tachycardiás beteg kezdeti kivizsgálása}

A beteg kivizsgálása során az alapvető kardiológiai vizsgálatokon kívül (anamnézisfelvétel, fizikális vizsgálat, 12-elvezetéses nyugalmi EKG, transztorakális echokardiográfia, laborvizsgálatok - beleértve pajzsmirigyfunkciót is) törekedni kell a ritmuszavar alatti EKG-készítésre is, hiszen ez a további diagnózist és a terápiás döntéseket nagyban befolyásolja. Esetenként további vizsgálatok is szükségessé válhatnak, mint a terheléses EKG, 24 órás EKG-monitorozás, transztelefonos EKG-felvételek, vagy loop recorder implantáció. Elektrofiziológiai vizsgálat (EPS) megfontolandó a definitív diagnózis megállapítására típusos panasz esetén akár ritmuszavar alatti EKG hiányában is, különösen ha katéterabláció is tervezett.

\section{TÁBLÁZAT. Supraventricularis tachycardiák osztályozása}

Pitvari tachycardiák

Sinus tachycardia

- Fiziológiás sinus tachycardia

- Inappropriate sinus tachycardia

Sinuscsomó reentry tachycardia

Fokális pitvari tachycardia

Multifokális pitvari tachycardia

Macro-reentry pitvari tachycardia (MRAT)

Cavotricuspidalis isthmus-dependens MRAT

- Típusos pitvari flutter, counter-clockwise; clockwise (reverz típusos flutter)

- Egyéb cavotricuspidalis isthmus-dependens MRAT

Nem cavotricuspidalis isthmus-dependens MRAT

- Jobb pitvari

- Bal pitvari

Pitvarfibrilláció

Atrioventricularis junkcionális tachycardiák

Atrioventricularis nodalis reentry tachycardia

- Típusos

- Atípusos

Nem re-entry mechanizmusú junkcionális tachycardiák

- Junkcionalis ektópiás tachycardia (fokális junkcionális tachycardia)

- Más, nem reentry variánsok

Atrioventricularis reentry tachycardiák

- Orthodrom (ide tartozik a permanens junkcionális reciprok tachycardia is)

- JAntidrom (az AV-csomón, vagy ritkábban másik járulékos kötegen keresztüli retrográd vezetéssel)

*A cikk elkészítésében egyforma szerepet vállalt, megosztott első szerzők.

A kézirat 2020. 04. 01-jén érkezett a szerkesztőségbe, 2020. 04. 08-án került elfogadásra. 


\section{Tachycardiák differenciáld diagnózisa}

Keskeny QRS ( $\leq 120$ ms) tachycardiák

A keskeny QRS oka a kamrák gyors aktivációja a HisPurkinje-rendszeren keresztül, ami azt valószínúsíti, hogy a ritmuszavar a His-kötegtöl proximálisan ered. Mindazonáltal, a His-köteg korai aktivációja előfordulhat magas septalis VT esetében is, relative keskeny QRS-t eredményezve (110-140 ms).

Keskeny QRS-tachycardiák differenciáldiagnózisának alapja a ritmuszavar alatt készült EKG-n gyakran megtalálható P-hullám felismerése (szükség esetén a Lewis-elvezetések felhelyezésével, vagy akár oesophagealis elvezetéssel) (1. ábra).

\section{Széles QRS (>120 ms) tachycardiák}

Széles QRS-tachycardia lehet VT, illetve Tawara-szárblokkal vagy járulékos kötegen át anterográd levezetett SVT (gyakoriságuk rendre 80\%-15\%-5\%). A VT helyes diagnózisa kritikus fontosságú az ellátás szempontjából, mivel az SVT-k kezelésére alkalmazott gyógyszerek gyakran ártalmasak lehetnek VT esetén. Emiatt a széles QRS-tachycardiát VT-ként kell kezelni, amíg annak ellenkezője be nem bizonyitható.

SVT széles QRS-sel járhat az alábbi esetekben:

1. Tawara-szár-blokkal levezetett SVT. Ez lehetéséges már meglévő szárblokk, vagy ún. frekvenciafüggő szárblokk (általában jobb Tawara-szár-blokk) esetén.

2. Antidrom AVRT, amely során a járulékos köteg által anterográd irányban levezett ingerület retrográd az AV-csomón keresztül, vagy másik járulékos kötegen keresztül vezetődik vissza a pitvarra.

3. Járulékos köteg által anterográd irányban levezett SVT, amelynél a járulékos köteg a ritmuszavar mechanizmusában aktívan nem vesz részt, csupán bystanderként vezeti le az ingerületet a kamrákra (pl.: pitvarfibrilláció, pitvari tachycardia, pitvari flutter vagy AVNRT esetén).

4. SVT, a QRS-t kiszélesítő gyógyszerek vagy ioneltérések esetén.

5. Pacemaker-mediálta tachycardia esetén.

\section{A tachycardiák akut kezelése, biztos diagnózis hiányában \\ Reguláris tachycardiák \\ Keskeny QRS ( $\leq 120$ ms) tachycardiák}

A SVT-vel élö páciensek gyakran fordulnak meg a sürgősségi ellátóhelyeken. Amennyiben a páciens hemodinamikailag stabil, az akut ellátásban első lépésben a nem gyógyszeres terápia alkalmazható.

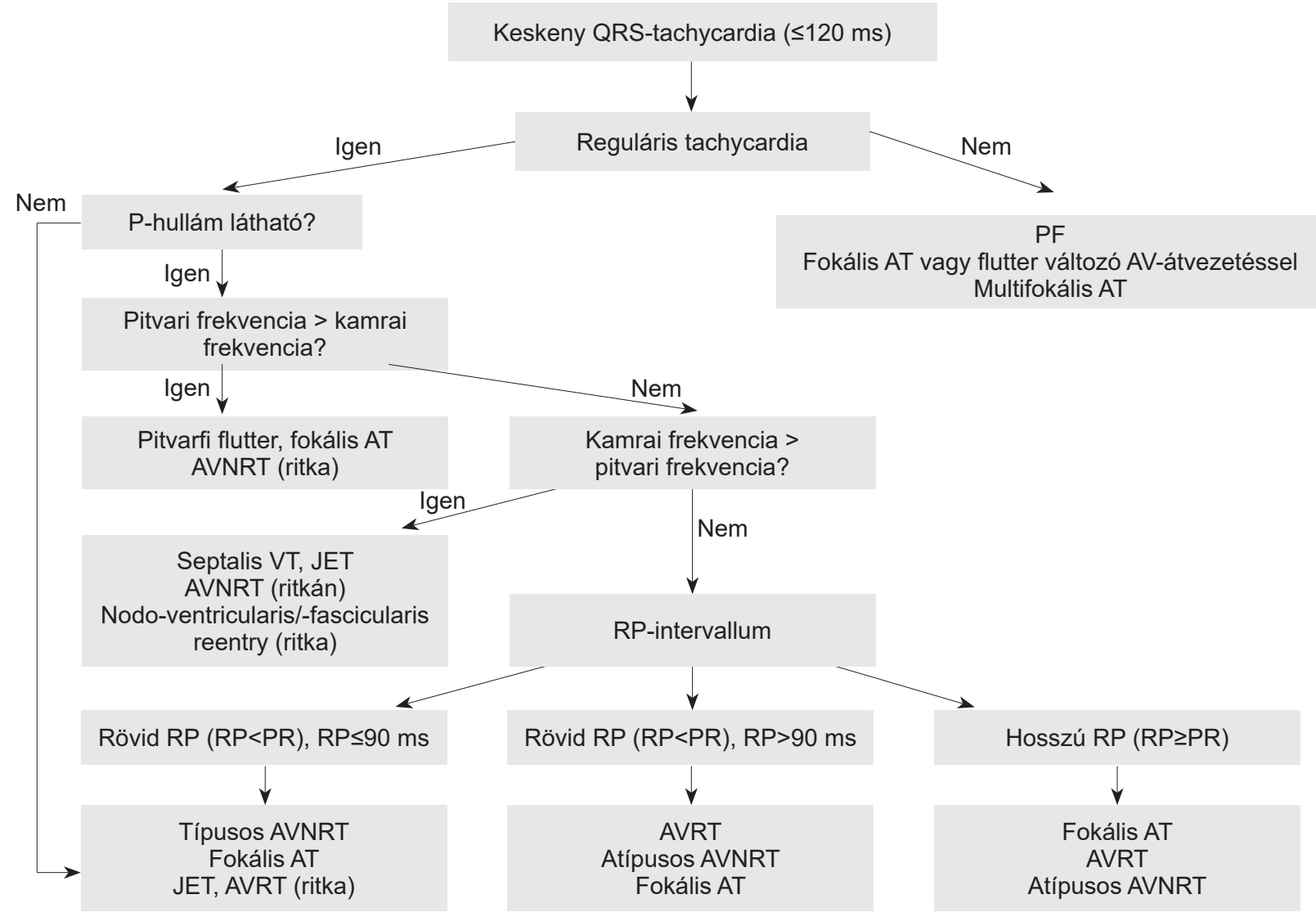

1. ÁBRA. Tachycardiák differenciáldiagnózisa. (AT = pitvari tachycardia, AV = atrio-ventricularis, AVNRT = atrio-ventricularis nodalis reentry tachycardia, AVRT = atrio-ventricularis reentry tachycardia, JET = junkcionális ektópiás tachycardia, $\mathrm{PF}=$ pitvarfibrilláció, $\mathrm{VT}=$ kamrai tachycardia) 
A vagusmanőverek olyan módszerek, amelyek a carotis interna receptorait stimulálják, ennek hatására a nervus vagusban acetilkolin szabadul fel, ami lassítja a szívfrekvenciát és az AV-csomó elektromos vezetőképességét. A Valsalva-manőver biztonságos, és nemzetközileg elfogadott elsővonalbeli terápiás lehetőség, amelynek hatékonysága fokozható, ha a manővert félig hanyattfekvő helyzetben végezzük, passzív lábemeléssel.

Carotis sinus masszázst nyújtott nyak, illetve a nyomással ellentétes irányban fordított fej mellett kell kivitelezni. Egyszerre mindig csak egyik oldalon végezhető, és 5 másodpercnél ne legyen hosszabb. Kerülendő olyan betegeknél, akinek anamnézisében tranziens iszkémiás attak vagy stroke szerepel, illetve akinek carotis zöreje hallható.

Amennyiben ezen manőverek ineffektívek, adenozin adása javasolt (6-18 mg iv. bolus) - IB. Ennek hatástalansága esetén az alábbi gyógyszerek használatosak:

- iv. verapamil vagy diltiazem - Ila, B;

- iv. béta-blokkoló - Ila, C.

Amennyiben a vagusmanőverek és a gyógyszeres terápia nem effektív, vagy ha a beteg hemodinamikailag instabil, szinkronizált DC-kardioverzió javasolt (IB).

\section{Széles QRS (>120 ms) tachycardiák}

A széles QRS-tachycardiás beteg ellátása is a hemodinamikai státusz függvénye. Hemodinamikailag instabil beteg esetén természetesen szinkronizált DC-kardioverzió javasolt (IB).

Amennyiben a beteg hemodinamikailag stabil, az alábbi terápiás lehetőségek állnak rendelkezésre:

- vagusmanőverek (IC),

- adenozin megfontolandó, ha a vagusmanőverek hatástalanok, és a nyugalmi EKG-n nincs preexcitáció (Ila, C),

- iv. procainamid megfontolandó, ha a vagusmanőverek és adenozin hatástalan (Ila, B),

- iv. amiodaron megfontolható, ha a vagusmanőverek és az adenozin hatástalan (Ilb, B),

- szinkronizált DC-kardioverzió javasolt, ha a gyógyszeres kezelés hatástalan a tachycardia megszüntetésére (IB).

Verapamil adása ismeretlen etiológiájú széles QRS-tachycardia esetén nem javasolt (IIIB)!

\section{Irreguláris tachycardiák}

Az irreguláris széles QRS-tachycardia leggyakrabban pitvarfibrilláció. Ritkán lehet polimorf VT, sőt még ritkábban monomorf VT is lehet irreguláris. Hemodinamikailag instabil, irreguláris, széles QRS-tachycardiák választandó akut kezelése az elektromos kardioverzió. Amennyiben hemodinamikailag tolerált, irreguláris keskeny QRS-tachycardiát látunk, azt pitvarfibrillációnak kell valószínűsíteni és frekvenciakontroll (béta-blokkolókkal vagy kalciumcsatorna-blokkolókkal), illetve elektív kémiai vagy elektromos kardioverzió közül választhatunk, miután az adekvát tromboembólia-profilaxist biztosítottuk.

\section{A supraventricularis tachycardiák típusai}

\section{Pitvari aritmiák}

Sinus tachycardia

A sinus tachycardia $>100 /$ perc frekvenciájú sinusritmust jelent. Az EKG-n a P-hullám pozitív I, II és aVF elvezetésben, míg bifázisos/negatív V1-ben.

\section{Fiziológiás sinus tachycardia}

Kiváltásában szerepet játszanak különböző szimpatikus hatások, betegségek, élvezeti szerek vagy illegális drogok. Kezelése alapvetően a kiváltó okok megszűntetése.

\section{Inappropriate sinus tachycardia (IST)}

Fiziológiás kiváltó ok nélküli sinus tachycardia. Nyugalomban is emelkedett szívfrekvencia jellemzi, minimális terhelés hatására jelentős tachycardia lép fel (tehát itt egész nap emelkedett a szívfrekvencia, az átlagfrekvencia >90/ perc). Kezelésében alapvető a reverzibilis okok kivizsgálása és kezelése, ezen felül a gyógyszeres kezelés alkalmazása javasolt (ivabradin \pm béta-blokkolók [lla, B] vagy béta-blokkolók [Ila, C]). A rendelkezésre álló limitált adatok alapján IST esetén nem megfelelő hatékonysága miatt a katéteres abláció csak kivételes esetben alkalmazandó.

\section{Sinuscsomó reentry tachycardia}

A sinuscsomót is magába foglaló reentry kör alkotja, az IST-vel szemben paroxizmális jellegú. Terápiaként nondihidropiridin kalciumcsatorna-blokkolók (verapamil vagy diltiazem - Ilb, C), vagy katéteres abláció (Ila, C) is alkalmazható.

\section{Posturalis ortosztatikus tachycardia szindróma (POTS)} A POTS egy klinikai szindróma, amelyet $>30$ sec-os állást követő, >30/min szívfrekvencia-emelkedés (vagy > 40/min 12-19 év között) jellemez, ortosztatikus hipotenzió nélkül.

Kezelés céljából rendszeres, progresszív fizikális tréning (Ila, B), napi > 2-3 liter víz és 10-12 gramm nátrium-klorid fogyasztása (Ilb, C) javasolható. Ezen életmódbeli változtatások hatástalansága esetén midodrin, alacsony dózisú nem szelektív béta-blokkoló, vagy pyridostigmin (IIb, B), esetleg ivabradin (Ilb, C) megfontolható.

\section{Fokális pitvari tachycardia}

A fokális AT egy diszkrét pontból kiinduló, centrifugálisan terjedő, >100/perc frekvenciájú, organizált pitvari ritmus. A kamrai frekvencia az AV-csomó vezetésétől függ.

Hemodinamikailag stabil betegek esetén különböző gyógyszerek (pl.: adenozin - Ila, B, iv. béta-blokkolók - Ila, C, iv. verapamil/diltiazem - Ila, C, i.v. ibutilid/i.v. flecainid/iv. propafenon/iv. amiodaron - Ilb, C), vagy ezek hatástalansága esetén szinkronizált DC kardioverzió (IB) alkalmazása javasolt. Hosszú távú kezelésként, különösen ha a tachycardia incessant jellegű vagy tachycardiomyopathiát okoz, katéterabláció (IB) választandó. Amennyiben a katéterablá- 
ció nem preferált, illetve nem kivitelezhető, béta-blokkolók vagy non-dihidropiridin kalciumcsatorna-blokkolók, vagy propafenon vagy flecainid megfontolandó (Ila, C). Az előzőek hatástalansága esetén ivabradin és béta-blokkoló, vagy amiodaron megfontolható (Ilb, C).

\section{Multifokális pitvari tachycardia}

A multifokális pitvari tachycardia olyan gyors irreguláris ritmus, amelyet legalább 3 különböző P-hullám morfológia jellemez.

Amennyiben lehetséges, a ritmuszavarért felelős alapbetegség kezelése javasolt (IC), továbbá szóba jön per os verapamil/diltiazem és szelektív béta-blokkolók is adhatók (Ila, B). Visszatérő, balkamra-diszfunkciót okozó, gyógyszerrefrakter esetben AV-csomó-abláció és pace-elés (preferálandó a biventricularis vagy His-pacing) alkalmazható (Ila, C).

\section{Macro-reentry pitvari aritmiák}

A macro-reentry pitvari tachycardiák (MRAT) lehetnek cavotricuspidalis isthmus (CTI) dependensek, vagy nem-CTI-dependensek.

A CTI-dependens flutterek között a leggyakoribb a típusos pitvari flutter, amikor a macro-reentry kör a tricuspidalis billentyü körül forog, és a kör legkeskenyebb része a CTI. A körbeforgás iránya általában óramutató járásával ellentétes (counterclockwise - típusos flutter); míg ritkábban óramutató járásával megegyező irányú (clockwise - reverz típusos flutter). Nem-CTI dependens MRAT a jobb pitvarban általában sebészeti beavatkozás után, a bal pitvarban leggyakrabban korábbi abláció esetén fordulhat elő.

Pitvari flutter esetén az antikoaguláns terápiát a pitvarfibrillációhoz hasonló irányelvek alapján javasolják. Hemodinamikailag stabil beteg akut kezelésében választhatunk számos gyógyszeres terápiás lehetőség közül (pl.: iv. ibutilid, vagy iv./per os dofetilid - IB; iv. béta-blokkolók/iv. non-dihidropiridin kalciumcsatornablokkolók - Ila, B). Alacsony energiájú ( $\leq 100$ J bifázisos) elektromos kardioverzió (IB) szintén választható kezelés. Amennyiben a beteg implantált pacemakerrel/defibrillátorral rendelkezik, magas frekvenciájú pitvari ingerlés (burst pacing) szintén végezhető a pitvari flutter megszüntetése céljából (IB). Amennyiben a fentiek nem elérhetők, vagy nemkívánatosak, iv. amiodaron megpróbálható (IIb, C). Pitvari flutter esetén propafenon és flecainid adása nem javasolt (IIIB).

Hosszú távú kezelésként mind CTI-dependens (IA), mind nem CTI-dependens esetben (IB) is a katéterabláció az elsőként javasolt terápiás lehetőség. Amennyiben az abláció nem jön szóba, vagy nemkívánatos, béta-blokkolók vagy nondihidropiridin kalciumcsatorna-blokkolók (Ila, C), vagy amiodaron adása (Ilb, C) lehetséges. Ha a fentiek hatástalanok, és a beteg perzisztáló, magas kamrafrekvenciájú macro-reentry pitvari tachycardiában szenved, AV-csomó-abláció és pacemaker-implantáció (biventricularis vagy His-pacing) megfontolandó (Ila, C).
Atrioventricularis junkcionális aritmiák

A leggyakoribb atrioventricularis junkcionális aritmia az atrioventricularis nodalis reentry tachycardia (AVNRT). A nem reentry mechanizmusú tacyhcardiák relatíve ritkák, közülük leggyakoribb az ektópiás junkcionális tachycardia, amely általában kongenitális aritmia vagy gyakrabban csecsemőkori nyitott szívműtét utáni korai posztoperatív szakban fordul elő.

Az AVNRT az AV-csomó (AV-junkció) területén forgó re-entryt jelent, a reentry kör pontos helye valójában nehezen megfogható, annak kis mérete miatt.

Az esetek több mint 95\%-a típusos, ún. „slow-fast” AVNRT. Az atípusos formákon belül az új irányelv állásfoglalása szerint nincs lényeges gyakorlati értelme a „fast-slow” és „slow-slow” típusok elkülönítésének, mivel bizonyos atípusos AVNRT-esetek be sem lennének sorolhatók ezekbe a csoportokba.

Mind típusos, mind atípusos AVNRT esetén kitűnő eredménnyel végezhető katéteres abláció (IB), és az AVblokk esélye minimális, ha kellő körültekintéssel jár el az operatőr. Amennyiben a katéterabláció nem preferált vagy nem kivitelezhető, p.o. diltiazem/verapamil vagy béta-blokkoló (Ila, B) rendszeres szedése javasolt.

\section{Atrioventricularis aritmiák}

Az atrioventricularis reentry tachycardiák (AVRT) anatómiailag jól definiálható reentry köre két szárból tevődik össze: egyik szára az atrioventricularis csomó és HisPurkinje-rendszer (AVN-HPS), a másik szára egy járulékos köteg (AP). Ritka esetben az AVRT mindkét szára lehet egy-egy járulékos köteg is. A kötegek a myocardium egyszeres vagy többszörös nyalábjai, amelyek áthidalják a pitvar és kamra közötti annulus fibrosust, ezáltal kikerülve a fiziológiás ingerületvezető rendszert. Ha a köteg anterográd vezet, a nyugalmi EKG-n általában egyértelmü preexcitáció látható, ekkor a köteget „manifeszt”-nek nevezzük. Ezzel ellentétben, a köteget „concealed”-nek (rejtett) nevezzük, ha kizárólag retrográd vezet, ekkor nyugalmi EKG-n preexcitáció nincsen.

Wolff-Parkinson-White (WPW) szindróma esetén manifeszt kötegvezetés van jelen (preexcitációt okozva), és általában visszatérő tachycardia-epizódokkal jár együtt. Az AV-csomón keresztüli vezetés iránya alapján megkülönböztetünk orthodrom és antidrom AVRT-t. Kezelésüket a 2. táblázatban foglaljuk össze.

A paroxizmális pitvarfibrilláció (PF) a WPW-s betegek $50 \%$-ában fordul elő. A PF, amennyiben anterográd vezető, rövid refrakteritású köteg van jelen, „fast-broad-irregular" tachycardiát okozhat, igen magas kamrai frekvenciát eredményezve, amely kamrafibrillációba degenerálódhat, így életveszélyes ritmuszavart jelent. Hemodinamikailag stabil preexcitált pitvarfibrilláló beteg esetén akut ellátás részeként ibutilid/procainamid (Ila, B), valamint flecainid/propafenon (Ilb, B) alkalmazható, hemodinamikai instabilitás esetén természetesen akut kardioverzió szükséges!

Adenozin, digoxin, béta-blokkolók, diltiazem, verapamil 


\section{TÁBLÁZAT. Atrioventricularis reentry tachycardia kezelése}

Akut kezelés

- Vagusmanőverek

- Orthodrom AVRT esetén adenozin vagy iv. verapamil/diltiazem/iv. béta-blokkolók

- Antidrom AVRT esetén iv. ibutilid/iv. procainamid/iv. flecainid/ profanenon vagy iv. amiodaron

- Szinkronizált DC-kardioverzió

Krónikus kezelés

- Katéteres abláció tünetes, visszatérö AVRT-epizódok esetén - Béta-blokkolók/non-dihidropiridin kalciumcsatorna-blokkolók, ha a nyugalmi EKG-n nincs preexcitáció, és ha az abláció nem preferált - Propafenon vagy flecainid, ha az abláció nem preferált

és amiodaron nem javasolt, sőt potenciálisan károsak lehetnek preexcitált PF estén (III, B)!

A tünetmentes preexcitációval rendelkező betegek a hirtelen szívhalál szempontjából potenciálisan veszélyeztetett populációt képeznek, ezért náluk rizikóstratifikáció szükséges, leginkább elektrofiziológiai vizsgálat formájában! Ezen betegek menedzsmentjét a lenti folyamatábrán mutatjuk be (1. ábra).

\section{Tünetmentes preexcitációval bíró páciensek rizikóstratifikációja és kezelése}

Alapvetően elmondható, hogy a járulékos kötegek rizikóstratifikációja speciális képzettséget igényel, így ezt érdemes elektrofiziológus szakember bevonásával végezni. Mivel a noninvazív rizikóbecslés gyakran nehezen értékelhető, ezért a jelenlegi szakmai irányelv az invazív elektrofiziológiai vizsgálatot részesíti előnyben. Magas rizikójú köteg, illetve foglalkozás esetén a köteg ablációja javasolt, de akár bizonyítottan alacsony rizikójú kötegnél is elvégezhető, válogatott esetekben, tapasztalt centrumban (2. ábra).

\section{Supraventricularis tachycardia veleszületett szívfejlödési rendellenességgel élő́ felnőtttekben}

A ritmuszavarok oka lehet maga a szívfejlődési hiba, vagy korábbi szívsebészeti beavatkozás miatti hegképződés. Diagnózisa és kezelése bonyolult, ezért az ilyen betegek kezelése speciális elektrofiziológiai eszközöket és képzettséget igényel.

\section{Supraventricularis tachycardia terhességben}

Az SVT-k a morbiditás és mortalitás magasabb rizikóját hordozzák magukban terhesség során. Olyan szempontokat is figyelembe kell vennünk, mint a magzat jóléte, a ritmuszavar és kezelésének hatása a terhesség egészére, a szülés folyamatára és a szoptatásra. Katéterabláció lehetőség szerint a második trimeszterre, illetve azutánra halasztandó, de gyógyszerrefrakter, rosszul tolerált tachycardia esetén korábban is szükséges lehet. llyen esetben az abláció tapasztalt centrumban kell, hogy történjen, nonfluoroszkópiás elektroanatómiai térképező rendszer használatával. Ideális esetben az abláció a terhesség előtt kell megtörténjen fogamzóképes korú nők esetén, ha az anamnézisükben tünetes PSVT-epizódok szerepelnek.

Az elektromos kardioverzió terhesség alatt is biztonságos, és ez kell legyen az első választandó kezelés, hemodinamikailag instabil aritmiák esetén.

\section{Tachycardia-indukálta cardiomyopathia}

A tachycardia-indukálta cardiomyopathia (TCM), pontosabban aritmiaindukálta cardiomyopathia olyan balkamra-diszfunkciót jelent, amelynek reverzibilis oka

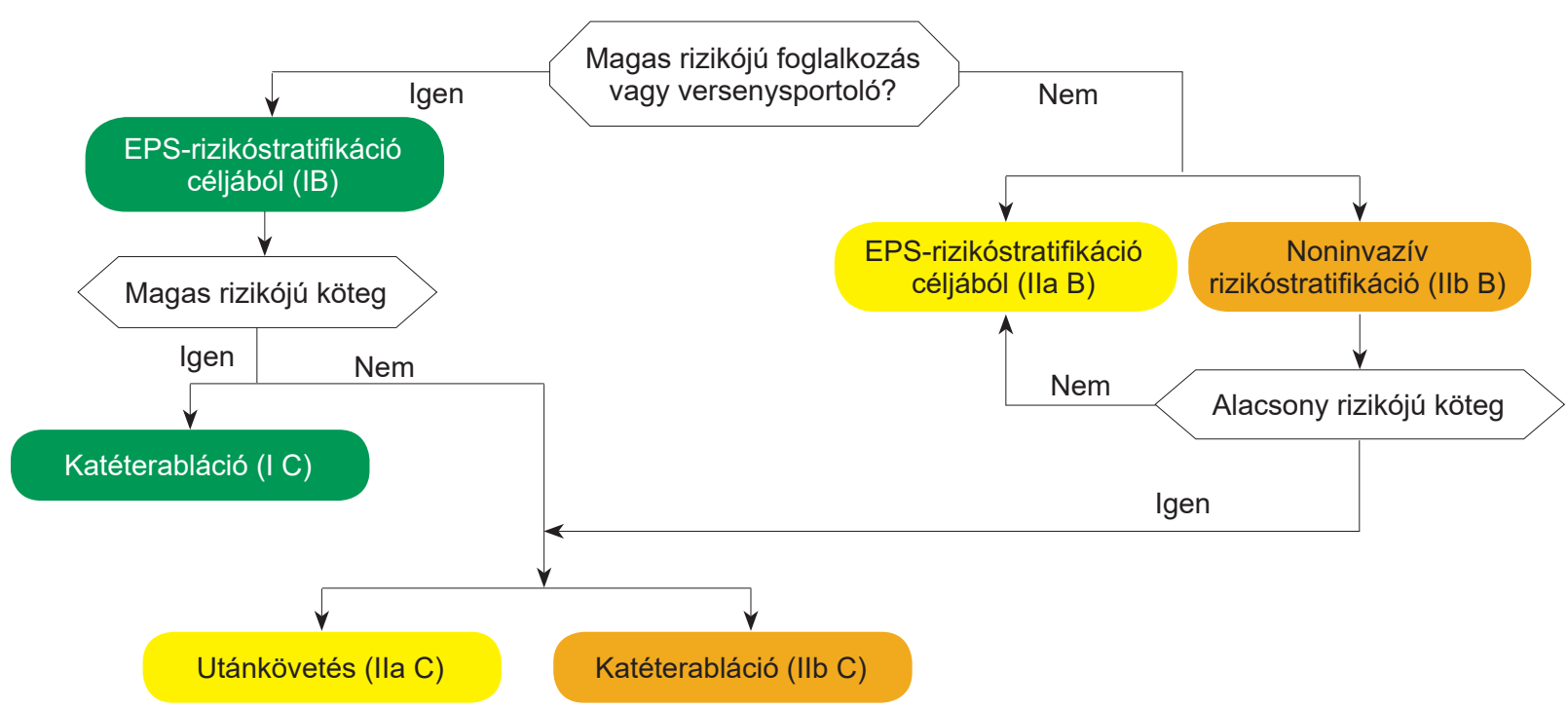

2. ÁBRA. Tünetmentes preexcitációval bíró páciensek rizikóstratifikációja és kezelése (EPS = elektrofiziológiai vizsgálat. Magas rizikójú foglalkozás pl.: pilóta, hivatásos sofőr) 
TÁBLÁZAT. Versenysportra vonatkozó ajánlások supraventricularis aritmiával rendelkezdő sportolóknál

Alkalmassági kritérium

Pitvari extrasystolia

AVRT, vagy pitvarfibrilláció és WPW-szindróma

Tünetmentes kamrai preexcitáció

Paroxizmális supraventricularis tachycardia (AVNRT, AVRT rejtett kötegen keresztül, vagy pitvari tachycardia)
Nincs tünet, nincs szívbetegség

Abláció kötelező. Sportolás egy hónappal az abláció után engedélyezhető, ha nincs rekurrencia Magas rizikójú betegekben az abláció kötelező. Sportolás egy hónappal az abláció után engedélyezhető, ha nincs rekurrencia.

a) Abláció javasolt. Sportolás egy hónappal az abláció után engedélyezhető, ha nincs rekurrencia

b) Abláció nemkívánatos, vagy nem lehetséges

\section{Alkalmasság}

Minden sport

Minden sport

Minden sport

a) Minden sport

b) Minden sport, kivéve ahol magas az eszméletvesztés kockázata

AVNRT = atrioventricularis nodalis reentry tachycardia; AVRT = atrioventricularis reentry tachycardia; WPW = Wolff-Parkinson-White

lehet perzisztens tachycardia, vagy gyakori kamrai extrasystolia. A leggyakoribb okok: septalis köteg mediálta incessant AVRT, rapid pitvarfibrilláció, idiopátiás VT, pitvari tachycardia, gyakori extrasystolia.

\section{Supraventricularis tachycardia és sport}

Gyakran előforduló supraventricularis aritmiával bíró sportolók kivizsgálása javasolt az esetleges strukturális szívbetegség, elektroliteltérés, pajzsmirigy-diszfunkció, illetve teljesítménynövelő szerek használatának kizárása céljából (3. táblázat).

\section{SVT és jármúvezetés}

A soförök két csoportját különítjük el. Az 1. csoportba tartoznak a motorosok, személygépkocsit és kisebb jármüveket (pótkocsi nélkül) „úrvezetők”. A 2. csoportba tartoznak a $3500 \mathrm{~kg}$ feletti járművet vezetők, illetve a 8 főnél több utast szállító járművet vezető „hivatásos soförök”. Mindkét kategóriára külön ajánlások vonatkoznak, amelynek részleteit a teljes szakmai irányelv tartalmazza.

\section{Kulcsfontosságú üzenetek}

- Vagusmanőverek és adenozin a választandó akut kezelés SVT esetén, illetve fontos diagnosztikus információkkal is szolgálhatnak.

- Verapamil nem javasolt ismeretlen etiológiájú széles QRS-tachycardia esetén.

- Minden reentry és a legtöbb fokális aritmia esetén fel kell ajánlani a katéterablációt elsővonalbeli kezelésként a betegnek, a várható haszonról és kockázatról való felvilágosítást követően.

- Az AVNRT (típusos és atípusos) ablációja esetében az AV-blokknak gyakorlatilag alig van rizikója.

- Ne használjunk sotalolt SVT-vel rendelkező betegekben.

- Ne használjunk flecainidet/propafenont bal Tawara-szár-blokk, iszkémiás-, vagy strukturális szívbetegség esetén.
- Ne használjunk amiodaront preexcitált pitvarfibrilláció esetén.

- Tünetmentes pre-excitációval bíró páciensek esetén 5-böl 1 betegnél várható járulékos köteg mediálta aritmia kialakulása az utánkövetés során.

- A szívmegállás, illetve VF rizikója kb. 2,4/1000 fö/év a tünetmentes preexcitációval bíró betegek esetében.

- Noninvazív rizikóstratifikáció esetleg használható tünetmentes preexcitáció esetén, de prediktív értéke mérsékelt.

- Invazív rizikóstratifikáció javasolt elektrofiziológiai vizsgálattal tünetmentes preexcitáció esetén, amennyiben a páciens magas rizikójú foglalkozást üz, vagy versenysportoló.

- Ha a beteg az elektrofiziológiai vizsgálat alapján magas rizikójú járulékos köteggel rendelkezik, a katéterablációt el kell végezni.

- Hacsak lehetséges, tartózkodni kell minden antiaritmiás gyógyszer alkalmazásától a terhesség első trimeszterében. Ha béta-blokkolók adása szükséges, úgy csak béta-1 szelektív szerek javasoltak (kivéve atenolol).

- Ha abláció szükséges terhesség alatt, nonfluoroszkópiás térképezés használata javasolt.

- A tachycardiomyopathia diagnózisa fel kell merüljön SVT-vel bíró betegeknél, csökkent bal kamrai ejekciós frakció esetén.

- Abláció a javasolt kezelés SVT okozta tachycardiomyopathia esetén.

- AV-csomó-abláció, biventricularis/His pacing-gel kombinálva megfontolandó, ha az SVT ablációja sikertelen.

\section{Nyilatkozat}

A szerzők kijelentik, hogy az összefoglaló közlemény megírásával kapcsolatban nem áll fenn velük szemben pénzügyi vagy egyéb lényeges összeütközés, összeférhetetlenségi ok, amely befolyásolhatja a közleményben bemutatott eredményeket, az abból levont következtetéseket vagy azok értelmezését. 3812-3813. DOI: 10.1093/eurheartj/ehz837 